\title{
The status and determinants of rural household food insecurity in North Shewa Zone, Oromia Region, Ethiopia
}

\author{
Nigusu Abera (D) 1*, Shewadinber Mekonin (D)2 \\ ${ }^{1}$ Department of Agricultural Economics, Salale University, Ethiopia \\ ${ }^{2}$ Department of Rural Development and Agricultural Extension, Salale University, Ethiopia
}

\begin{abstract}
Food insecurity and undernutrition are significant challenges to the economic growth of Ethiopia. The objectives of this study were to identify the status and determinants of food insecurity for households targeted under a productive safety net program. About 392 beneficiary households were selected using multistage random sampling methods. The household food balance model and multiple linear regression models were used to measure household food insecurity levels and identify factors affecting food insecurity. According to the food balance model output, all sample households targeted under the program were food insecure. This revealed that the total daily energy available to the sample households was less than $2100 \mathrm{kcal}$ per adult equivalent. Moreover, the multiple regression model output depicts that family size, sex of the respondents, total farm owned by the respondents, livestock size, credit utilization, household participation in community organization, household access to off/non-farm income, and household access to saving habit had a significant effect on food insecurity status of households. Therefore, in order to reduce the food insecurity status of households policymakers should focus on strengthening household saving habits, expanding off/non-farm activities, promoting family planning, and strengthening the credit services.
\end{abstract}

\section{Introduction}

Food security is a state or a condition in which people experience unlimited physical and economic access to safe, sufficient, and nutritious food to meet their dietary needs or food preferences for a productive, healthy and active life (FAO, 2000). According to the World Bank/Ethiopia (2015) report, Ethiopia is one of Africa's fastest growing populations and economies. Despite increasing investment in agricultural extension work and input utilization, agricultural productivity remains low by international standards due to land degradation, drought, lack of irrigation, and constraints in input utilization (WFP and CSA, 2019). This brings Ethiopia to face high levels of food insecurity, ranking as one of the hungriest countries in the world (Global Hunger Index, 2009). Although the level and intensity vary, food insecurity exists in many parts of developing countries (Degefa, 2005). The cause of food insecurity varies depending on factors affecting the four pillars of food security (food availability, food access, food utilization and food stability). Limited resource and increased food price affecting many households of the world including Ethiopia are the common factors that affect food insecurity (Carter et al., 2010; Belachew et al., 2012).
To decrease the prevalent chronic food insecurity, the government of Ethiopia launched the most extensive rural social protection program called Productive Safety Net Program (PSNP) aimed to fill the household food gap, increase community assets, mitigate shocks such as drought, and ultimately attain food security (Devereux et al., 2006; MoARD, 2014). The program is planned to be implemented for five years, at the end of which PSNP beneficiaries who have received predictable transfers and complementary interventions throughout the program period will be expected to graduate out of dependence on external support, except during food crises (Arega, 2012).

Among the 13 districts found in North Shewa Zone, 5 districts namely Abichugnea, Wuchale, Jidda, Kimbibit, and Kuyu are the beneficiary of productive safety net program (North Shewa Zone Agriculture and Natural Resource Office, 2020). However, majority of beneficiary households targeted under the program are not food self-sufficient. Therefore, this study measures the status and determinants of households' food insecurity in the study area. To achieve these objectives primary data was collected from 392 beneficiary households participated in public work during the 2019/20 production year. 


\section{Materials and methods}

\subsection{Sampling techniques and sample size determination}

Purposive and multistage random sampling techniques were used to select the beneficiary households in the study area. In the first stage, among 13 district existed in North Shewa Zone, 5 districts were purposively selected based on the districts access to safety net program. In the second stage, 10 sample kebeles (smallest administrative unit in the Ethiopian government structure) were purposively selected from each district based on the kebeles access to safety program. In the third stage, beneficiary households in each sample kebeles were proportionally distributed and randomly selected for interview (Table 1). The total sample size is calculated by using the simplified Yamane (1967) formula specified in equation 1 .

$\mathrm{n}=\frac{\mathrm{N}}{1+\mathrm{N}(e)^{2}}=\frac{19,635}{1+19,635(0.05)^{2}}=392$

Where;

$\mathrm{n}=$ Sample size

$\mathrm{N}=$ Total beneficiaries households participated in public work in the sample district (at least for five years)

$\mathrm{e}=$ margin of error $(0.05)$

Table 1. Sample size determination procedures

\begin{tabular}{|c|c|c|c|}
\hline Name of districts & Name of kebeles & Total households & Sample households \\
\hline \multirow[t]{2}{*}{ 1. Kuyu } & Jila Qerensa & 91 & 13 \\
\hline & Tamsasa Roge & 24 & 4 \\
\hline \multirow[t]{2}{*}{ 2. Abichugnea } & Ano Akabdo & 137 & 20 \\
\hline & Doyo Dawe & 166 & 24 \\
\hline \multirow[t]{2}{*}{ 3. Wuchale } & Nono & 178 & 26 \\
\hline & Walanso Aroji & 119 & 17 \\
\hline \multirow[t]{2}{*}{ 4. Jidda } & Gango & 894 & 131 \\
\hline & Wanya Daga Nasri & 681 & 100 \\
\hline \multirow[t]{2}{*}{ 5. Kimbibit } & Daka Bora & 187 & 27 \\
\hline & Gara Catu & 205 & 30 \\
\hline Total & & 2,682 & 392 \\
\hline
\end{tabular}

Source: NSZANRO data (2020)

\subsection{Data collection techniques}

The primary data was collected through a survey and key informant's interview. To generate quantitative and qualitative data at the household level, a household survey was undertaken by developing questionnaires. Before full implementation, questionnaires were pre-tested, and necessary adjustments are made. To supplement primary data, a key informant interview was also conducted.

\subsection{Methods of data analysis}

Descriptive statistics like frequencies, percentage, mean and standard deviation were used to analyze data. Both SPSS (statistical package for social science) software and Microsoft excel was used to generate the output. Following Degefa's (1996) household food balance model specified in equation 2 was used to estimate the food insecurity level of sample farmers.

$$
\mathrm{NGA}=(\mathrm{GP}+\mathrm{GB}+\mathrm{FA}+\mathrm{GG})-(\mathrm{HL}+\mathrm{GU}+\mathrm{GS}+\mathrm{GV})
$$

Where;

NGA $=$ Net grain available to farmers in one year

$\mathrm{GP}=$ Total grain produced by sample farmer in one year

$\mathrm{GB}=$ Total grain bought by sample farmer in one year

$\mathrm{FA}=$ Amount of food aid obtained by a farmer in one year

$\mathrm{GG}=$ Total grain acquired as a gift or remittance by farmers in one year

$\mathrm{HL}=$ Post-harvest losses in a given year

$\mathrm{GU}=$ Amount of grain kept for seed by farmers in one year

GS $=$ Amount of grain sold by a farmer in one year

$\mathrm{GV}=$ Amount of grain given to others in one year

The threshold for categorizing households into food secure and food insecure is $2100 \mathrm{kcal} /$ day/adult equivalent
(AE). Accordingly, sample households with daily caloric consumption of less than $2100 \mathrm{kcal} /$ day/AE were considered food insecure while greater than or equal to 2100 $\mathrm{kcal} /$ day/AE were food secure (Kaluski et al., 2002). The household food balance assessment covers a period between September 2019 and September 2020. In this model, the data used for the computation is generated through field survey except the estimates given for the Amount of grain reserved for seed and post-harvest loss. Following Mesay (2001), the estimate for total grain kept for seed, and post-harvest loss was $5 \%$ and $10 \%$ of complete grain produced by sample households, respectively.

Previous researchers used the binary logistic regression model to estimate the determinants of food security (Ayalneh and Shimelis, 2009; Achenef et al., 2016; Moroda et al., 2018) due to the binary nature of a dependent variable. However, this study used multiple linear regression models to analyze the determinants of rural households' food insecurity because the dependent variable is continuous (total amount of energy consumed by households per day). Following Gujarati (1995), the model is specified as follows:

$$
\begin{aligned}
Y_{i}=\beta_{o}+\beta_{1} x_{1}+\beta_{2} x_{2}+\beta_{3} x_{3}+\beta_{4} x_{4}+\beta_{5} x_{5}+\beta_{6} x_{6}+\beta_{7} x_{7}+\beta_{8} x_{8} \\
+\beta_{9} x_{9}+\beta_{10} x_{10}+\beta_{11} x_{11}+\beta_{12} x_{12}+\beta_{13} x_{13} \\
+\varepsilon
\end{aligned}
$$

Where; Yi= Amount of energy available to household per adult equivalent per day

$\beta_{0}=$ Intercept

$\beta_{1}$ to $\beta_{13}=$ Vectors of parameter to be estimated

$\varepsilon=$ Error term

$\mathrm{X}_{1}$ to $\mathrm{X}_{13}=$ Vectors of explanatory variables included in the model as listed below:

$\mathrm{X}_{1}=$ Family size 
$\mathrm{X}_{2}=$ Sex of household head

$\mathrm{X}_{3}=$ Farm size

$\mathrm{X}_{4}=$ Livestock size

$\mathrm{X}_{5}=$ Access to credit

$\mathrm{X}_{6}=$ Participation in community organization

$\mathrm{X}_{7}=$ Access to off/non-farm income

$\mathrm{X}_{8}=$ Access to saving

$\mathrm{X}_{9}=$ Soil fertility

$\mathrm{X}_{10}=$ Access to extension

$\mathrm{X}_{11}=$ Education level of household head

$\mathrm{X}_{12}=$ Age of household head

$\mathrm{X}_{13}=$ Distance from market

\subsection{Definition, measurement, and hypothesis of the study variables}

Dependent variables: It is a continuous variable and defined as the total amount of energy consumed by household per AE per day.

Independent variables: It is a dummy and/or continuous variable and defined as the vectors of explanatory variables hypothesized to affect rural households' food insecurity status in the study area (Table 2).

Table 2. Summary of explanatory variables included in the model

\begin{tabular}{llc}
\hline Variables Name & Types of variables & Expected effect \\
\hline 1. Age of household head & Continuous & + \\
2. Sex of household head & Dummy & + \\
3. Education level of household head & Continuous & + \\
4. Family size & Continuous & - \\
5. Livestock size & Continuous & + \\
6. Access to credit services & Dummy & + \\
7. Participation in off/non-farm activities & Dummy & + \\
8. Access to extension services & Dummy & + \\
9. Farm size & Continuous & + \\
10. Soil fertility & Dummy & + \\
11. Distance from market & Continuous & - \\
12. Access to off/non-farm income & Dummy & + \\
13. Participation in community organization & Dummy & +
\end{tabular}
Source: Own construction based on literature (2021)

\section{Results and discussion}

\subsection{Socioeconomic and farm characteristics of the respondents}

Education level of household head: Education is the key to improve agricultural production, productivity and food security level of household. The survey result show that, the average education level of household head was 0.59 grades ranging from 0 to 4 grades implying that sample households in the study area did not attend more education (Table 3 ).

Table 3. Socioeconomic and farm characteristics of the respondents

\begin{tabular}{lcccc}
\hline Variable name & Mean & Std. dev. & Min & Max \\
\hline Education level of household head & 0.59 & 0.17 & 0.00 & 4.00 \\
Family size & 3.94 & 0.76 & 1.75 & 6.00 \\
Age of household head & 54.56 & 10.93 & 28.00 & 87.00 \\
Farm size & 0.91 & 0.33 & 0.50 & 3.00 \\
Livestock size & 2.97 & 0.83 & 0.39 & 6.24 \\
Distance from market & 36.98 & 14.33 & 5.00 & 90.00 \\
\hline
\end{tabular}

Source: Survey results (2021)

Family size: The numbers of family size determine the amount of energy available to household. On average, sample household owned 3.94 adult equivalents ranging from 1.75 and 6 adult equivalents respectively. This implies that, there is a variation in the number of family size between sample household in the study area (Table 3).

Age of household head: Age is a proxy variable for experience of households in agricultural production. The average age of sample household was 54.56 year with minimum and maximum of 28 and 87 year respectively. This implies that the average age of sample households lies within the economically productive age groups (Table 3 ).

Farm size: The total farm sizes owned by households determine the amount agricultural production and hence, food security level of households. The average farm size owned by sample households 0.91 ranging from 0.5 to 3 hectare respectively (Table 3 ).

Livestock size: The numbers of livestock owned by households determine the amount cash available to households during food shortage and hence, enhance household access to food. The average livestock size owned by sample household was 2.97 ranging from 0.39 to 6.24 tropical livestock unit respectively (Table 3 ).

Distance from market: The availability of market near to household home determines household access to food grain which in turn enhances household food security. The average 
distance of household home from nearest market was 36.98 walking minutes ranging from 5 and 90 walking minutes respectively (Table 3 ).

\subsection{Institutional, social and demographic characteristics of the respondents}

Access to credit: Credit enhances household access to agricultural inputs which in turn improve the agricultural production and hence, food security level of the households. The survey result depicted that, about $59.44 \%$ of the household was used credit from microfinance institution. This implies that, majority of the sample households were obtained the credit services (Table 4).

Table 4. Institutional, demographic and social characteristics of sample respondents

\begin{tabular}{lcc}
\hline Variable name & Freq. & $\%$ \\
\hline Access to credit (1=Yes) & 233 & 59.44 \\
Access to extension (1=Yes) & 210 & 53.57 \\
Access to saving (1=Yes) & 164 & 41.84 \\
Participation in community organization (1=Yes) & 201 & 51.28 \\
Access to off/non-farm income (1=Yes) & 106 & 27.04 \\
Soil fertility (1=Yes) & 252 & 64.29 \\
Sex of household head (1=Male) & 244 & 62.24 \\
\hline
\end{tabular}

Source: Survey results (2021)

Access to extension: Extension is a key to improve agricultural production and productivity which in turn improve the food availability and food security level of households. About $53.57 \%$ of the sample households were obtained the extension service while the remaining $46.43 \%$ were not obtained. This implies that, majority of the sample households were obtained the extension services (Table 4).

Access to saving: Saving improve households access to cash deposited which in turn helps to enhance the purchasing power of the households especially during the food shortage. The survey results show that, about $41.84 \%$ of households had access to money saved in microfinance institution. This implies that, majority of the sample households did not have the culture of saving money in bank/microfinance institution (Table 4).

Participation in community organization: Participation in community based organization like ikub and idir enhance households access to cash which in turn improve household purchasing power and hence, food security status. According to the results, about $51.28 \%$ of the sample households were participated in community based organization (Table 4).

Access to off/non-farm income: Access to off/non-farm income may enhance the purchasing power of the households and hence, improve production and food security status of household. The survey result depicted that, about

$27.04 \%$ of the sample household had access to off/non-farm income while the remaining $72.96 \%$ had not implying that, majority of the sample household did not have access to off/non-farm income (Table 4).

Soil fertility: Household access to fertile land may enhance the amount of production and productivity of the crops and hence, improve food security of the households. The results show that, about $64.29 \%$ of the sample had access to fertile land while the remaining was not implying that majority of the land owned by households are fertile (Table 4).

Sex of household head: Being male headed is positively correlated with being food secure due to the fact that male had more access to outside information than female. The survey result shows that, about $62.24 \%$ of the sample households were male implying that majority of the sample households are male (Table 4).

\subsection{Food security status of sample households in the study area}

The major food grains consumed by sample households were cereals like Teff, wheat and barley and vegetables like potato, tomato, garlic and onion (Table 5). Identifying the types of food grain consumed by household was used to calculate the amount of energy available to sample households in the study area. On average, the amount of food grains consumed by sample households per year was 350.98 $\mathrm{kg}$ implying that the average amount of energy available to sample households was per year $59,057.85 \mathrm{kcal}$ with minimum and maximum of $14,991.75 \mathrm{kcal}$ and $132,682 \mathrm{kcal}$ respectively (Table 6). In other words, the average amount of energy available to households per adult equivalent (AE) per day was $429.29 \mathrm{kcal}$ with minimum and maximum of $93.34 \mathrm{kcal}$ and 1,311.91 kcal respectively (Table 6). When compared to the threshold/standard, all sample households targeted under productive safety net programs were food insecure. This could be attributed to many socioeconomic, political, institutional, and demographic factors affecting food security.

\subsection{Factors affecting rural households food insecurity in the study area}

Among 13 hypothesized explanatory variables, 8 variables namely family size, sex of household head, farm size, livestock size, access to credit, participation in community organization, access to off/non-farm income, and access to saving significantly affected household food insecurity (Table 7). These significant variables are interpreted as follow.

The number family member had positive relationship with households' food insecurity at $\mathrm{P}<0.01$. This result revealed that as the number of family members increased by one unit, food insecurity increased by 83.70 units (Table 7). This is due to the fact that large family members can compete with the existing scarce resources and hence, enhance household food insecurity. Ergando And Belete (2016) also found a positive relationship between household food insecurity and family size during their study on the analysis 
of Household Food Insecurity and its Covariates in Girar Jarso district, Oromia Regional State, Ethiopia and hence, stated that with existing high rate of unemployment and less employment opportunity coupled with low wage rate payment, additional family member shares the limited resources that lead the household to become food insecure.

Table 5. Types of food grain consumed by households in the study area

\begin{tabular}{lcc}
\hline $\begin{array}{l}\text { Access to food grain }(\mathrm{n}=392) \\
(1=\text { yes; } 0=\text { No) }\end{array}$ & Freq. & $\%$ \\
\hline Teff (Yes) & 153 & 39.03 \\
Wheat (Yes) & 376 & 95.92 \\
Barley (Yes) & 253 & 65.54 \\
Sorghum (Yes) & 27 & 6.89 \\
Maize (Yes) & 4 & 1.02 \\
Bean (Yes) & 2 & 0.51 \\
Pea (Yes) & 3 & 0.77 \\
Chickpea (Yes) & 2 & 0.51 \\
Oat (Yes) & 2 & 0.51 \\
Garlic (Yes) & 392 & 100 \\
Onion (Yes) & 392 & 100 \\
Potato (Yes) & 392 & 100 \\
Tomato (Yes) & 392 & 100 \\
\hline Sorce: Sureyresils & & \\
\hline
\end{tabular}

Source: Survey results (2021)

Table 6. Amount of energy available to households in the study area

\begin{tabular}{lcccc}
\hline Variables & Mean & Std. Dev. & Min & Max \\
\hline $\begin{array}{l}\text { Amount of food grain available to } \\
\text { households per year (kg) }\end{array}$ & 350.98 & 88.30 & 128 & 805 \\
$\begin{array}{l}\text { Amount of energy available to households } \\
\text { per year (kcal) }\end{array}$ & $59,057.85$ & $15,457.98$ & $14,991.75$ & 132,682 \\
$\begin{array}{l}\text { Amount of energy available to household } \\
\text { per AE per day (kcal/AE/day) }\end{array}$ & 429.29 & 153.03 & 93.34 & $1,311.91$ \\
\hline
\end{tabular}

Source: Survey results (2021)

A negative and significant relationship is observed between sex (male-headed) and food insecurity at $\mathrm{P}<0.1$. This means as the number of male-headed households increased by one unit, the households' food insecurity decreased by 26.47 units (Table 7). This is because males headed households have high chance to participate in various income-generating activities and social organizations than female-headed. Desalegn and Yu (2017) study also found that sex of household was statistically significant and positively correlated food security ad stated that the probability of being food security is high when the household head is male due to the fact that Males have the capability to participate in various income generating activities while the female is disadvantageous because they are often limited to certain income earning activities and overloaded with households reproductive roles.

As expected, farm size had negatively and significantly affected households' food insecurity at $\mathrm{P}<0.01$. This result shows that when farm size owed by sample farmers increased by one unit, food insecurity decreased by 89.83 units (Table 7). The probable reason is that households with large farm sizes had more capacity to produce and diversify crops which in turn increased the consumption and exchange of food grain which in turn decreased food insecurity. Moroda et al. (2018) on their study on the determinants of food insecurity of rural households in Boset district of Ethiopia explain that having more cultivable land is strongly associated being food secure at less than $1 \%$ significance level and hence, households with more cultivable land could produce more food, or even may diversify their crop to insure for crop failure.

The relationship between livestock size and food insecurity was negative and significant at $\mathrm{P}<0.05$. This result depicts that increasing the number of livestock by one unit would result in 10.77 unit decrease in household food insecurity (Table 7). This is because livestock can be used to obtain income through exchange especially during food shortages and hence, reduce food insecurity. A similar result is also accepted by Ayalneh and Shimelis (2009) and Amare et al. (2020).

Households food insecurity is negatively affected by access to credit services at $\mathrm{P}<0.01$ implying that as households' access to credit services increases by one unit, food insecurity decreases by 33.85 units (Table 7). This is because credits enhance households' participation in income generating activities and also enhance the purchasing power of the agricultural inputs. Desalegn and Yu (2017) study on Analysis of Factors Affecting Household Graduation from Ethiopian Productive Safety Net Program in Babile district, Oromia Region, Ethiopia also found that Access to credit to credit have a significant and positive relationship with households food self-sufficiency due to the fact that credit gives the households an opportunity to be involved in income generating activities which in turn enhance the financial capacity and purchasing power of the beneficiaries.

Participation in community organization was negatively affect households' food insecurity at $\mathrm{P}<0.01$. This reveals 
that as households' participation in community organization increased by one unit, food insecurity level of households' can be decreased by 50.04 units (Table 7). This is because community based organization enhance household access to support during food shortage and hence, reduce food insecurity. Mulu and Workneh (2017) also found positive and statistically significant relationship between participation in social organization and female household food insecurity in west Shewa zone, Oromia region, Ethiopia.

Table 7. Factors affecting food insecurity level of households in the study area

\begin{tabular}{llcc|c}
\hline Independent Variables & Coef. & SE. & $\mathrm{T}$ & $\mathrm{P}>|\mathrm{t}|$ \\
\hline Education level of household head & 3.328 & 4.099 & 0.81 & 0.417 \\
Family size & $-83.702^{* * *}$ & 6.576 & -12.73 & 0.000 \\
Sex of household head & $26.474^{*}$ & 13.507 & 1.96 & 0.051 \\
Age of household head & -0.591 & 0.407 & -1.45 & 0.147 \\
Farm size & $89.831^{* * *}$ & 13.533 & 6.64 & 0.000 \\
Livestock size & $10.768^{* *}$ & 5.187 & 2.08 & 0.039 \\
Access to extension & 15.298 & 10.779 & 1.42 & 0.157 \\
Access to credit & $33.853^{* * *}$ & 9.424 & 3.59 & 0.000 \\
Distance from market & -0.076 & 0.262 & -0.29 & 0.773 \\
Participation in community organization & $50.040^{* * *}$ & 12.358 & 4.05 & 0.000 \\
Access to off/non-farm income & $55.812^{* * *}$ & 11.597 & 4.81 & 0.000 \\
Soil fertility & -11.735 & 13.445 & -0.87 & 0.383 \\
Access to saving & $57.401 * * *$ & 9.532 & 6.02 \\
Constant & 562.006 & 38.326 & 14.66 \\
\hline Number of observation & 392 & & 0.000 \\
F(13, 378) & 78.23 & & 0.000 \\
$\mathrm{R}^{2}$ & 0.7290 & & \\
Adjusted R & & & \\
Source: Survey results (2021), SE: Standard Error & $R^{2}:$ Coefficient Determination,$* *$ and *** represent statistical significance at 10\%, 5\% and 1\% respectively
\end{tabular}

Households' access to off/non-farm income positively affected food insecurity level at $\mathrm{P}<0.01$ implying that as access to off/non-farm income increased by one unit, households' food insecurity decreased by 55.81 units (Table 7). This is because access to off/non-farm income would enhance the purchasing power of the households and could serve as livelihood diversification strategies which in turn reduce food insecurity. Ergando And Belete (2016) also found positive relationship between household food security and access to off/non-farm income.

Table 8. Conversion factor of family size into adult equivalent

\begin{tabular}{lcc}
\hline Age group (years) & Male & Female \\
\hline$<10$ & 0.6 & 0.60 \\
$10-13$ & 0.9 & 0.80 \\
$>13$ & 1.0 & 0.75
\end{tabular}

Source: Storck et al., 1991

The relationship between household saving habits and food insecurity was negative and significant at $\mathrm{P}<0.01$. This result depicts that as household saving habits increased by one unit, food insecurity of households' decreased by 57.40 units (Table 7). This is because saving increases the ability of households' to cope up with shock which may bring unexpected changes in food production, prices and income and hence, reduce food insecurity. This result is supported by the finding of Lilian et al. (2013) study on Household Food Security and Commercialization among Smallholder Farmers in Kenya stating that households' access to savings can be instrumental in raising their ability to produce food and access it from the market and hence ensuring food security.

\section{Conclusion}

This study aimed to measure the status of rural household food insecurity and identify its determinants in the study area. The survey result depicted that, all sample households targeted under the productive safety net program were food insecure. This means that the daily energy available to households was less than $2100 \mathrm{kcal}$ per adult equivalent. This is due to lack of credit service, large family size, lack of saving habit, lack of participation in community organization, and lack of large livestock size. Therefore, in order to enhance the rural households "food security" in the study area, the policymakers should focus on the expansion of credit services, promotion of family planning, expansion of the off/non-farm activities, and enhancing the household saving habit.

\section{Compliance with Ethical Standards}

\section{Conflict of Interest}

The authors declare that they have no conflict of interest.

\section{Authors' Contributions}

Nigusu Abera: Participated in all research activities (data collection, analysis and manuscript preparation). Shewadinber 
Mekonin: Participated in data collection and manuscript preparation.

\section{Ethical approval}

Not applicable.

\section{Funding}

This study was supported by Salale University.

\section{Data availability}

Not applicable.

\section{Consent for publication}

Not applicable.

\section{Acknowledgement}

The authors warmly thank Salale University for funding this research project. Moreover, we feel great thanks to everyone who contributed for the success of this study.

\section{Abbreviations}

CSA: Central Statistics Agency

FAO: Food and Agricultural Organization

MoARD: Ministry of Agriculture and Rural Development

NSZANRO: North Shewa Zone Agriculture and Natural Resources Office

WFP: World Food Program

\section{References}

Achenef, M., Alemayehu, W., \& Abera, K. (2016). Level and determinants of food insecurity in East and West Gojjam zones of Amhara Region, Ethiopia: a community based comparative cross-sectional study. BMC Public Health, 16, 503.

Amare, W.A., Mulusew, K., Yenesew, F., \& Hayimro, E. (2020). Prevalence and associated factors for rural households' food insecurity in selected districts of east Gojjam zone, northern Ethiopia. BMC Public Health, 20, 202.

Arega, B. (2012). Productive safety nets program and household level graduation in drought-prone areas of the Amhara region of Ethiopia: A case study in Lay Gaint district. Ethiopian Journal of Environmental Studies and Management, 5(4), 604 612.

Ayalneh, B., \& Shimelis, A. (2009). Household Level Determinants of Food Insecurity in Rural Areas of Dire Dawa, Eastern Ethiopia. African Journal of Food Agriculture Nutrition and Development, 9, 9.

Belachew, T., Lindstrom, D., Gebremariam, A., Jira, C., Hattori, MK., Lachat, C., Huybregts, L., \& Kolsteren, P. (2012). Predictors of chronic food insecurity among adolescents in Southwest Ethiopia: A Longitudinal Study. BMC Public Health, 12, 604.

Carter, K. N., Lanumata, T., Kruse, K., \& Gorton, D. (2010). What are the determinants of food insecurity in New Zealand and does this differ for males and females?. Australian and New Zealand journal of public health, 34(6), 602-608.

Degefa, T. (1996). Belg crop production as a strategy of Households' Food security: A comparative study of Belg
Grower and non-Belg farmers in Munessa Woreda, Arsi Zone. MA Thesis, Addis Ababa University, Ethiopia.

Degefa, T. (2005). Rural Livelihoods, Poverty and Food Insecurity in Ethiopia: A Case Study at Erenssa and Garbi Communities in Oromiya Zone, Amhara National Regional State. Doctoral Dissertation at NTNU.

Desalegn, Y.W., \& Yu, L. (2017). Analysis of factors affecting household graduation from ethiopian productive safety net program (PSNP): The case of Babile District, Oromia Region, Ethiopia. Journal of Economics and Sustainable Development, 8,18 .

Devereux, S., Sabates, W., Slater, R., Mulugeta, T., Tefera, D., Borwon, T., \& Amdissa, T. (2006). Ethiopia's Productive Safety Program (PSNP): Assessment report: Institute of development studies.

Ergando, H. M., \& Belete, D. H. (2016). Analysis of household food insecurity and its covariates in Girar Jarso Woreda, Oromia Regional State, Ethiopia. Journal of Economics and Sustainable Development, 7(3), 16-30.

FAO (2000). The state of food insecurity in the world. Rome.

Global Hunger Index (2009). International Food Policy Research Institute. http://www.ifpri.org/publication/2009-global-hungerindex-key-facts-and-findings.

Gujarati, DN. (1995). Basic econometrics. $3^{\text {rd }}$ Edn. McGraw-Hill Inc., New York.

Kaluski, DN., Ophir, E., \& Amede, T. (2002). Food security and nutrition: The Ethiopian case for action. Public Health Nutrution, 5(3), 373-381

Lilian, K., Raphael, G., \& Millicent, O. (2013). Household Food Security and Commercialization of Smallholder Farmers in Kenya, a Paper Prepared for the International Conference of the African Association of Agricultural Economists. Tegemeo Institute of Agricultural Policy and Development.

Mesay, M. (2001). Study on Rural Households Food Security of Kuyu Woreda, Oromia Regional State. MA Thesis, Addis Ababa University.

MoARD (2014). Productive Safety Net Programme (PSNP) Programme Implementation Manual (Revised). Addis Ababa: Ministry of Agriculture and Rural Development (MoARD) of Ethiopia.

Moroda, G. T., Tolossa, D., \& Semie, N. (2018). Food insecurity of rural households in Boset district of Ethiopia: a suite of indicators analysis. Agriculture \& Food Security, 7(1), 1-16.

Mulu, D., \& Workneh, A. (2017). Determinants of Rural Femaleheaded Households' Food Security in Ambo District, West Shewa Zone, Oromia Regional State, Ethiopia. Journal of Science and Sustainable Development, 5(1), 73-87.

NSZANRO (2020). North Shewa Zone Agriculture and Natural Resource Office report.

Storck, H., Bezabih, E., Berhanu, A., Borowiecki, A. and Shimelis W.H. (1991). Farming Systems and Farm Management Practices of Smallholders in the Hararghe Highlands. Farming System in Practices of Resource Economics in the Tropics, Vol. 11, Wissenschaftsverlag, Vauk, Keil KG, Germany.

World Bank/Ethiopia (2015). Press release on A Unique Economic Strategy Delivering High Growth, Addis Ababa, Ethiopia.

WFP and CSA (2019). Comprehensive Food Security and Vulnerability Analysis (CFSVA): Executive Summary. Ethiopia.

Yamane, T. (1967). Statistics, an introductory analysis, 2nd Edition. New York, USA.

Copyright: (C) 2022 by the authors. Turkish Journal of Food and Agriculture Sciences is licensed under a Creative Commons AttributionNonCommercial-NoDerivatives 4.0 International License 